\title{
IMPLEMENTASI UNDANG-UNDANG NOMOR 20 TAHUN 2003 TENTANG SISTEM PENDIDIKAN NASIONAL DI BLITAR
}

\author{
Eni Irawati, Mahasiswa Fakultas Hukum, Universitas Islam Balitar Blitar, E-mail : \\ eniira237@gmail.com \\ Weppy Susetyo, Dosen Fakultas Hukum, Universitas Islam Balitar, Blitar, E-mail: \\ weppy_s@yahoo.co.id
}

\begin{abstract}
ABSTRAKSI
Pemerintah dan Pemerintah Daerah wajib menjamin tersedianya dana guna terselenggaranya pendidikan bagi setiap warga negara yang berusia tujuh sampai lima belas tahun sesuai UndangUndang Nomor 20 Tahun 2003 tentang Sistem Pendidikan Nasional. Implementasi dari substansi hukum tersebut urgen diteliti mengingat pendidikan sebagai penentu kualitas sumber daya manusia. Penelitian hukum empiris di Kota Blitar menunjukkan bahwa Pemerintah Kota Blitar dalam kerangka sistem pendidikan nasional, memberlakukan kebijakan APBD Pro Rakyat dengan pendidikan gratis untuk semua jenjang pendidikan di Kota Blitar, dilengkapi penyediaan fasilitas gratis atas sepatu, seragam, buku, alat tulis, bus sekolah, tas, tablet, SPP, uang gedung, uang saku, dan sepeda gratis. Kebijakan pendidikan APBD Pro Rakyat ini, mengalami sejumlah hambatan dari keluarga anak usia sekolah, kekurang memadainya kemampuan pemerintah dalam mengalokasikan anggaran Program Pendidikan Gratis, ketidakmerataan penyebaran lembaga sekolah, dan adanya perusahaaan yang mempekerjaan anak sekolah menengah pertama.
\end{abstract}

Kata Kunci: APBD Pro Rakyat, Pemerintah Kota Blitar, Pendidikan

\section{PENDAHULUAN}

Setiap warga negara Indonesia usia wajib belajar berhak mendapatkan pelayanan pendidikan yang bermutu dan orang tua/walinya berkewajiban memberi kesempatan kepada anaknya untuk mendapatkan pendidikan dasar. Sebagaimana sebuah kebijakan baru, setiap lahirnya kebijakan yang berubungan dengan hajat hidup orang banyak pasti akan melahirkan pro dan kontra di masayarakat. Artinya kebijakan tersebut ada yang mendukung dan ada yang menolak dengan segala argumennya. Oleh karena itu dalam tataran baik isi kebijakan, maupun dalam tataran pelaksanaanya perlu analisis yang menyeluruh agar didapatkan sebuah kebijakan yang tepat untuk kepentingan bangsa dan negara.

Pemerintah Daerah menjamin memberikan bantuan biaya penyelenggaraan dan/ atau pengelolaan pendidikan kepada siswa yang menjadi tanggungjawab Pemerintah Daerah yang menempuh pendidikan pada satuan pendidikan dasar dan pendidikan menengah yang diselenggarakan Pemerintah atau masyarakat/yayasan dalam wilayah Daerah.

Undang-Undang Nomor 20 Tahun 2003 tentang Sistem Pendidikan Nasional lebih lanjut telah mengatur beberapa pasal yang menjelaskan pendanaan pendidikan yaitu pada Pasal 11 Ayat 2 Pemerintah dan Pemerintah Daerah wajib menjamin tersedianya dana guna terselenggaranya pendidikan bagi setiap warga negara yang berusia tujuh sampai lima belas tahun. Lebih lanjut pada Pasal 12, Ayat (1) disebutkan bahwa setiap peserta didik pada setiap satuan pendidikan berhak mendapatkan beasiswa bagi yang berprestasi yang orangtuanya tidak mampu membiayai pendidikannya dan mendapatkan biaya pendidikan bagi mereka yang orangtuanya tidak mampu membiayai pendidikannya. Di samping itu disebutkan pula bahwa setiap peserta didik berkewajiban ikut menanggung biaya 
penyelenggaraan pendidikan, kecuali bagi peserta didik yang dibebaskan dari kewajiban tersebut sesuai dengan peraturan perundang-undangan yang berlaku.

APBD Pro Rakyat ini berorientasi pada 5 pilar yaitu, pertama APBD Pro Rakyat berorientasi agar masyarakat Kota Blitar menjadi masyarakat yang religius, beriman, dan bertaqwa kepada Tuhan Yang Maha Esa. APBD Pro Rakyat merupakan strategi agar tercapai kondisi masyarakat yang religius dan bertaqwa kepada Tuhan Yang Maha Esa, artinya seluruh pelaksanaan program pembangunan, pemerintahan, dan pelayanan kemasyarakatan di Kota Blitar harus senantiasa dilandasi aspek keimanan dan ketaqwaan kepada Tuhan Yang Maha Esa. Kedua, APBD Pro Rakyat berorientasi agar masyarakat Kota Blitar tidak lapar atau bisa sejahtera, jangan sampai ada kebutuhan dasar warga masyarakat yang tidak terpenuhi, jangan ada gizi buruk, busung lapar, dan sebagainya di kota ini. Ketiga, agar masyarakat kota blitar tidak sakit. APBD Pro Rakyat juga diterjemahkan agar masyarakat Kota Blitar bisa sehat. Artinya, apabila sakit harus memiliki akses layanan kesehatn yang memadai. Keempat, APBD Pro Rakyat diterjemahkan agar masyarakat Kota Blitar pintar atau tidak bodoh. Artinya, seluruh masyarakat kota blitar khususnya warga miskin harus mampu mengakses pendidikan. Kelima, APBD Pro Rakyat dimaknai agar masyarakat Kota Blitar senantiasa dalam suasana yang aman dan kondusif. karena semua aktivitas pemerintah dan masyarakat Kota Blitar baru akan berjalan dengan tertib dan lancar apabila ada suasana yang aman, kondusif, sesuai semboyan rukun agawe santoso.

APBD/perubahan pro rakyat membutuhkan dukungan semua pihak. Pemerintah, DPRD, partai politik, dan masyarakat luas. Kitapun perlu menilai apakah Rancangan Anggaran Perubahan 2014 APBD Manggarai Barat pro masyarakat atau pro birokrasi. Jika ditelisik maka lebih menguntungkan birokrasi dari pada memenuhi kebutuhan riil dan atau dampak lebih luas kepada kebutuhan masyarakat luas, Kitapun perlu mempertanyakan lagi, penyusunan rancangan itu sesuai dengan regulasi atau mengangkangi regulasi terutama berkaitan dengan Pedoman Rancangan Anggaran Perubahan 2014. APBD pro rakyat tentunya mengenai berbagai aspek dasar kebutuhan rakyat, diantaranya pendidikan, kesehatan, ekonomi, tenaga kerja, pemberdayaan perempuan, kehidupan umat beragama, lingkungan hidup, informasi, hukum, penanganan bencana, dan sebagainya. Fungsi alokasi dimaksudkan agar APBD digunakan untuk kepentingan penyelenggaraan pemerintah sehingga pelayanan publik makin baik. Pemerataan pendapatan danpengentasan masyarakat miskin merupakan perwujudan fungsi distribusi. Sementara itu, fungsi stabilitas ditujukan untuk menciptakan lingkungan kondusif bagi kegiatan ekonomi, memperluas kesempatan kerja, stabilitas harga, dan pertumbuhan ekonomi.

Itu sebabnya mengapa keberpihakan tersebut harus dijadikan pilihan. APBD harus ditujukan sebesar-besarnya untuk belanja pelayanan dasar, khususnya pelayanan pendidikan, kesehatan, sarana air bersih, dan perluasan lapangan kerja. Semua itu berorientasi pada rakyat miskin sebagai upaya penanggulangan kemiskinan dengan tujuan akhir kesejahteraan seluruh rakyat.

Tingkat pendidikan yang tinggi sangat penting bagi negara-negara untuk dapat mencapai tingkat pertumbuhan ekonomi yang tinggi. ${ }^{1}$ _Analisis empiris cenderung mendukung prediksi teoritis bahwa negara-negara miskin harus tumbuh lebih cepat dari

${ }^{1}$ H.A.R. Tilaar, 50 Tahun Pembangunan Pendidikan Nasional 1945-1995,Jakarta: Grasindo, 1995, h.196. 
negara-negara kaya karena mereka dapat mengadopsi teknologi yang sudah dicoba dan diuji oleh negara-negara kaya. Beberapa siswa yang telah menunjukkan potensi yang tinggi untuk belajar, mungkin tidak mencapai potensi penuh akademis mereka, karena kesulitan keuangan.

Dengan melalui APBD yang pro rakyat terutama di bidang pendidikan maka Pemerintah Kota Blitar mampu mencanangkan Program Pendidikan gratis yang merupakan suatu program strategi Pemerintah Kota Blitar dalam meningkatkan kualitas pendidikan di Kota Blitar. Strategi ini dilakukan oleh Pemerintah Kota dengan cara memberikan bantuan sekolah gratis berupa SPP, berbagai perlengkapan dan kebutuhan siswa untuk sekolah, berbagai sarana juga diberikan seperti Bus sekolah gratis untuk mengantar siswa berangkat dan pulang sekolah serta sarana teknologi informasi berupa Tab untuk siswa lebih melek teknologi.

Hal ini terlihat dalam website Pemerintah Kota Blitar, terobosan kebijakan yang diambil Walikota Blitar tidak tanggung-tanggung, yaitu mengetrapkan pendidikan gratis di semua jenjang, SD - SLTP - SLTA sederajat. ${ }^{2}$ Seluruh kebutuhan dasar siswa dibiayai sepenuhnya dari APBD. Namun ada hal yang sangat disayangkan yaitu sampai dengan berakhirnya tahun 2016 ini, untuk pendidikan menengah (SMA/SMK) mulai awal tahun 2017 akan dikelola oleh Pemerintah Provinsi.

\section{METODE PENELITIAN}

Penelitian ini dilaksanakan mulai tanggal 14 Desember 2016 sampai 21 Desember 2016. Waktu penelitian kurang lebih 1 minggu, sesuai dengan ketentuan dan kebijaksanaan tempat penelitian yang bersangkutan. Berdasarkan permasalahan dalam penelitian ini termasuk dalam jenis penelitian empiris yang lebih memperhatikan fakta-fakta yang terjadi di lapang. Sedangkan dilihat dari sifatnya, penelitian ini termasuk penelitian deskriptif yaitu suatu penelitian yang bertujuan untuk memberikan data dan menganalisa serta membandingkan dengan peraturan yang ada.

Bentuk metode penelitian ini adalah mempergunakan jenis penelitian yuridis empiris, menggunakan data sekunder sebagai data awalnya, yang kemudian dilanjutkan dengan data primer, meneliti efektivitas suatu peraturan perundang-undangan dan meneliti hubungan antara berbagai gejala atau variabel sebagai alat pengumpul datanya terdiri dari studi dokumen, pengamatan dan wawancara. ${ }^{3}$ Sedangkan pendekatan empiris dimaksudkan untuk melihat berlakunya dan keefektifan Peraturan Walikota yang mengatur tentang fungsi, tujuan dan wewenang Pemerintahan Daerah di Kota Blitar dalam tindakan penyelenggaraan program APBD Pro Rakyat.

Tipe penelitian yang akan digunakan adalah diskriptif kualitatif, dengan metode pendekatan. Sehingga, dalam penelitian ini akan diperoleh hasil yang benar-benar sesuai dengan fakta yang ada dan berkembang. Untuk pendekatan yuridis dalam penelitian ini dimaksudkan untuk membahas Program APBD Pro Rakyat di bidang pendidikan yang

\footnotetext{
2 http:/ /www.blitarkota.go.id, diakses pada 8 Desember 2016.

${ }^{3}$ Bambang Sunggono, S.H.,M.S., Metodologi Penelitian Hukum, Jakarta: PT Raja Grafindo Persada, 2005, h.40.
} 
memberikan amanah kepada Pemerintah Daerah Kota Blitar dalam hal penyelenggaraannya yang akan berlangsung maupun yang sudah berlangsung sampai saat ini.

Data yang diperlukan dalam penelitian ini adalah data sekunder. Sedangkan jenis bahan hukum yang dipergunakan adalah bahan hukum sekunder dan bahan hukum tersier, yaitu pada bahan hukum sekunder yang digunakan adalah berupa Undang-Undang tentang Pemerintah Daerah maupun Undang-Undang tentang Sistem Pendidikan Nasional dan Peraturan Walikota, buku pedoman program APBD Pro Rakyat pada pendidikan di Kota Blitar, artikel dari majalah ilmiah serta artikel dari internet. Lalu alat pengumpul data yang dipergunakan adalah studi dokumen dan wawancara jika dianggap perlu. Kemudian metode penganalisisan dan pengkonstruksian data ialah metode kualitatif, karena metode kualitatif ini merupakan suatu cara penelitian yang menghasilkan data deskriptif-analitis serta bertujuan untuk mengerti atau memahami gejala yang akan diteliti. Serta bentuk hasil penelitiannya adalah deskriptif analisis.

Penulisan hukum ini menggunakan 3 (tiga) macam sumber hokum yaitu:

1. Bahan Hukum Primer digunakan pengamatan dilokasi penelitian.

2. Bahan Hukum Sekunder yang akan digunakan adalah berdasarkan Peraturan Walikota Blitar Nomor 08 Tahun 2011 tentang Pedoman Teknis Pengelolaan Belanja Subsidi, Hibah, Bantuan Sosial, Bantuan Keuangan dan Belanja Tak Terduga, Undang-Undang Nomor 20 tahun 2013 tentang Sistem Pendidikan Nasioanal yang mengamanatkan pemerintah agar mengaggarkan $20 \%$ untuk biaya pendidikan betul-betul jalan.

3. Bahan Hukum Tersier, berupa kamus hukum, ensiklopedia dan berita pada berbagai media massa.

Keseluruhan data yang diperoleh selama penelitian berlangsung, baik data primer, sekunder dan tersier, ditelaah dengan berdasarkan pada kerangka teoretik kemudian dianalisis dengan menggunakan metode analisis kualitatif. Hasil penalaran dalam analisis kualitatif tersebut pada akhirnya mendeskripsikan tentang berbagai kesimpulan untuk mengatasi permasalahan yang menjadi objek penelitian. Teknik pengumpulan data melalui observasi dimaksudkan adalah untuk melakukan pengamatan secara partisipatif tentang pelaksanaan program APBD Pro Rakyat terhadap pendidikan di Kota Blitar yang sampai sekarang masih berjalan.

Dalam penelitian ini juga dilakukan wawancara mendalam. Metode ini dimaksudkan untuk memperoleh informasi secara luas dari Pemerintah Kota Blitar serta tokoh-tokoh lain yang sekiranya perlu untuk di mintai keterangannya guna menambah sumber-sumber yang diperlukan. Terhadap data lapangan (primer) dikumpulkan dengan teknik wawancara yaitu dengan mengadakan komunikasi langsung kepada informan, dengan menggunakan pedoman wawancara guna mencari jawaban atas pelaksanaan program APBD Pro Rakyat terhadap pendidikan di Kota Blitar. Pewawancara mengajukan pertanyaan dengan yang diwawancarai yang memberikan jawaban atas pertanyaan tersebut. Pertanyaan yang diberikan dapat dikembangkan lebih lanjut bila mana ada hal-hal yang dirasakan memerlukan informasi lebih lanjut dan mendalam.

Teknik pengumpulan data dengan menggunakan dokumen sebagai data pendukung dalam penelitian ini. Dokumen dalam penelitian ini dapat berupa semua jenis rekaman/catatan lainnya, seperti surat-surat, memo/nota, pidato-pidato, buku harian, foto- 
foto, kliping berita koran, hasil-hasil penelitian, dan agenda kegiatan. Dalam penelitian ini penulis mengumpulkan dokumentasi yang berhubungan dengan pokok masalah.

\section{PROGRAM PENDIDIKAN APBD PRO RAKYAT SEBAGAI IMPLEMENTASI UNDANG- UNDANG NOMOR 20 TAHUN 2003 TENTANG SISTEM PENDIDIKAN NASIONAL DI BLITAR}

Lokasi instansi merupakan suatu hal yang terpenting bagi semua instansi, karena sangat mempengaruhi bagaimana kinerja instansi tersebut dan akan menentukan hasil dari kinerja sebuah instansi. Dengan demikian akan memudahkan masyarakat untuk berinteraksi secara langsung. Semua instansi pada dasarnya mempunyai tujuan yang sudah ditetapkan terlebih dahulu sebelum melaksanakan kegiatan. Yang dimaksud tujuan instansi disini adalah diharapkannya sebuah instansi secara jelas digunakan sebagai wadah untuk membantu pemerintah kota dalam menjalankan tugas-tugasnya.

Berangkat dari data dan informasi saat ini serta analisis isu-isu strategis yang berkembang dengan memperhitungkan potensi sumberdaya dan faktor strategis yang dimiliki oleh masyarakat Kota Blitar, maka visi Kota Blitar ditetapkan sebagai berikut : Menuju Masyarakat Kota Blitar Sejahtera yang Berkeadilan, Berwawasan Kebangsaan dan Religius Melalui APBD Pro Rakyat Pada Tahun 2015.

Adapun makna visi tersebut diatas adalah sebagai berikut:

1. Sejahtera yaitu terpenuhinya kebutuhan jasmaniah dan rohaniah dalam berbagai aspek kehidupan sebagai individu dan anggota masyarakat yang ditandai dengan meningkatnya derajat kesehatan, tingkat pendidikan dan pendapatan masyarakat, serta semakin kondusifnya lingkungan kehidupan sosial masyarakat.

2. Berkeadilan merupakan suatu sikap dan tindakan yang memperlakukan orang lainsesuai dengan fungsi, peran dan tanggung jawabnya serta memperhatikan hak dan kewajiban masyarakat. Dengan demikian proses pembangunan harus memperhatikan asas pemerataan sehingga manfaat dan hasil pembangunan dapat dinikmati oleh seluruh lapisan masyarakat.

3. Religius adalah kondisi masyarakat yang menjunjung norma-norma agama, berpegang teguh kepada ajaran agama sebagai landasan moral dan etika yang diimplementasikan dalam kehidupan sehari-sehari.

4. APBD Pro Rakyat mengandung makna bahwa APBD Kota Blitar dimanfaatkan sebesarbesarnya bagi upaya peningkatan kesejahteraan masyarakat Kota Blitar.

Misi merupakan rumusan umum mengenai upaya-upaya yang akan dilaksanakan untuk mewujudkan visi. Atas dasar makna misi dimaksud serta berlandaskan kepada makna visi Kota yang telah ditetapkan, Misi Kota Blitar periode 2011 - 2015 sebagai berikut :

1. Mewujudkan masyarakat yang berwawasan kebangsaan dan Berketuhanan Yang Maha Esa mengandung makna bahwa keseluruhan kegiatan pemerintahan, pembangunan dan kemasyarakatan didasarkan pada fungsi dan peran agama sebagai landasan moral dan etika serta diarahkan pada terwujudnya suatu tatanan sosial masyarakat yang memiliki karakter Nasionalis-Religius sebagai pengejewantahan nilai-nilai luhur yang bersumber dari agama, nasionalisme, dan kearifan lokal.

2. Meningkatkan kualitas pendidikan dan keterjangkauan pelayanan pendidikan pada hakekatnya penyelenggaraan pendidikan diarahkan pada upaya peningkatan kualitas 
serta peningkatan pelayanan pendidikan yang merata dan bisa dijangkau oleh seluruh lapisan masyarakat Kota Blitar serta berkeadilan sehingga akan tercapai tingkat pendidikan masyarakat yang lebih baik sehingga pada akhirnya mampu meningkatkan kesejahteraan, kemandirian, keluhuran budi pekerti, dan karakter kebangsaaan yang kuat.

3. Meningkatkan kualitas pelayanan kesehatan yang adil dan merata pada hakekatnya pelayanan kesehatan diarahkan pada upaya peningkatan kualitas serta peningkatan pemerataan pelayanan kesehatan sehingga bisa diakses seluruh lapisan masyarakat Kota Blitar secara adil untuk meningkatkan derajat kesehatan masyarakat.

4. Memantapkan pelaksanaan perekonomian daerah yang berbasis kerakyatan dan penanggulangan kemiskinan, mengandung makna bahwa pembangunan perekonomian daerah dilaksanakan dengan mengembangkan potensi ekonomi terutama dibidang pariwisata, perdagangan dan jasa serta harus berpihak kepada masyarakat menengah dan miskin dengan menitik beratkan kearah perluasan akses ekonomi bagi masyarakat dan pengembangan sektor koperasi, Usaha Mikro Kecil dan Menengah serta pelaku usaha informal untuk meningkatkan pendapatan masyarakat yang pada gilirannya mampu menurunkan angka kemiskinan.

5. Memantapkan Pelaksanaan Pembangunan Berkelanjutan yang Partisipatif berdasar Prinsip-prinsip Otonomi Daerah, berarti bahwa proses pembangunan yang dilaksanakan di Kota Blitar harus mampu mensinergikan aspek sosial, ekonomi dan lingkungan hidup serta memberikan peran yang lebih besar kepada masyarakat untuk terlibat didalam pelaksanaan proses pembangunan berkelanjutan dengan memperhatikan prinsip-prinsip otonomi daerah yang didukung oleh aparatur profesional dengan tata kelola pemerintahan yang baik.

Jumlah karyawan merupakan faktor yang sangat penting dalam menjalankan kinerja kantor, dikarenakan memegang peranan yang sangat penting sebagai hasil pekerjaan. Demikian pula dengan Bagian Hukum Sekretariat Daerah Kota Blitar dan Dinas Pendidikan Kota Blitar sangat berperan penting dalam membantu menjalankan tugas-tugas semua bagian-bagian yang ada di kantor. Secara kualitas memenuhi syarat yang baik telah ditetapkan berdasarkan kebijakan dari instansi.

\section{PELAKSANAAN PROGRAM APBD PRO RAKYAT DI BIDANG PENDIDIKAN KOTA BLITAR}

APBD pro rakyat sendiri mempunyai arti yang berarti mendukung hak-hak yang diinginkan oleh rakyat. Apbd Pro Rakyat membutuhkan semua dukungan berbagai pihak entah itu dari pemerintah, DPRD, Partai politik, dan masyarakat luas, yang dimana APBD Pro Rakyat tersebut tentunnya mampu mengenai aspek dasar kebutuhan rakyat, terutama di bidang pendidikan. Seperti yang kita ketahui pendidikan adalah hak yang harus diterima oleh setiap warga negara, terutama di Kota Blitar sebagaimana terumus dalam pembukaan Undang-undang bangsa yaitu mencerdaskan kehidupan bangsa.

Dalam Rencana Kerja Pemerintah Daerah Kota Blitar kebijakan yang ditetapkan adalah:

1. Meningkatkan Angka Partisipasi Kasar (APK) Taman Kanak - Kanak termasuk didalamnya Pendidikan Anak Usia Dini (PAUD). 
2. Mempertahankan Angka Partisipasi Kasar (APK) pada pendidikan dasar dan menengah diatas.

3. Mempertahankan tingkat lulusan Sekolah Dasar (SD).

4. Mengupayakan rata-rata nilai Ujian Nasional Sekolah Dasar di atas 6,5.

5. Meningkatkan prosentase lulusan Sekolah Menengah Pertama (SMP).

6. Meningkatkan rata-rata nilai Ujian Nasional SMP.

7. Meningkatkan prosentase lulusan Sekolah Menengah Atas (SMA) dan Sekolah Menengah kejuruan (SMK).

8. Meningkatkan prosentase lulusan Sekolah Menengah atas (SMA) dan Sekolah Menengah Kejuruan (SMK) rata-rata nilai Ujian Nasional.

9. Meningkatkan Pelaksanaan Kejar paket B dan paket C.

10. Meningkatkan prosentase guru yang telah berijazah sarjana / akta 4 .

11. Mengupayakan peningkatan prosentase guru yang telah memiliki sertifikat keprofesionalan mengajar.

12. Meningkatkan prestasi akademik dan non akedemik siswa dan tenaga pendidik di bidang seni, budaya dan olah raga

Tahun 2011 telah ditetapkan kebijakan yang didambakan masyarakat Kota Blitar yaitu Pendidikan Gratis untuk Semua Jenjang di Kota Blitar. Pendidikan Gratis disini bukan bersifat semu atau hanya janji kampanye belaka. Setiap anak usia sekolah wajib untuk Sekolah. Tidak boleh ada alasan tidak melanjutkan sekolah karena biaya. Tidak ada perbedaan dari golongan Atas, Menengah, ataupun Bawah, semuanya mendapat fasilitas sama.

Khusus fasilitas antar-jemput gratis tidak hanya dinikmati pelajar Kota Blitar, tetapi juga siswa dari Kabupaten Blitar. Siswa yang tercatat sebagai warga Kota Blitar, seluruh kebutuhan sekolahnya sudah dibiayai APBD, bahkan siswa berprestasi dan tidak mampu mendapatkan perangkat sabak atau tablet. Dengan digratiskannya semua biaya sekolah, dirinya semakin fokus belajar. Kecuali untuk biaya dalam perayaan Ulang Tahun Sekolah, pertandingan olahraga dan urusan pribadi lainnya seperti kas maupun foto kopi memang harus membayar sendiri.

Program tersebut membuat sekolah lebih fokus memacu prestasi. Siswa juga menjadi lebih disiplin dan tidak ada alasan absen karena menunggak biaya sekolah. Kalau ada yang bolos dan tertangkap satuan polisi pamong praja, ketentuannya kepala sekolah, guru bimbingan, dan konseling atau wali kelas dan orangtua wajib menjemput.

Upaya Pemkot Blitar menggratiskan berbagai biaya sekolah dan memberi fasilitas tablet didukung Dewan Pendidikan Kota Blitar. Pemberian fasilitas itu dinilai bermanfaat dan tak sia-sia. Gratis itu tidak identik murah dan berkualitas rendah. Diberi fasilitas gratis kalau ukurannya tidak pas atau tidak memikirkan pertumbuhan siswa akhirnya tidak cukup, sebaliknya tidak dapat digunakan. Kekhawatiran tentang pemberian fasilitas tablet kepada siswa. Tapi ketika itu disiapkan untuk menunjang belajar-mengajar dan mempermudah akses buku elektronik, itu dinilai sangat membantu siswa. Apalagi perangkat tersebut sudah dirancang tidak bisa untuk game dan membuka situs yang dilarang.

Program pendidikan gratis betul-betul dirasakan, dengan pendidikan gratis, orangtua tinggal fokus mencari nafkah dan menunjang kebutuhan referensi buku bagi anak-anaknya. Kalau pun membeli seragam sendiri itu untuk cadangan. 
Program ini digagas agar adanya semangat warga Blitar untuk melanjutkan pendidikan setinggi-tingginya. Sekolah gratis dan angkutan gratis juga diharapkan meningkatkan kesejahteraan warga. Angkutan kota yang sepi penumpang terikat kontrak sudah otomatis mendapatkan penghasilan dari APBD, mereka tidak perlu berebut penumpang anak sekolah. Bahkan di luar jam berangkat dan pulang sekolah, bisa mengangkut penumpang umum.

Dari penelitian yang didapatkan dari hasil wawancara bahwa beberapa fasilitas yang dinikmati warga terkait pendidikan gratis yakni, fasilitas sepatu, seragam, buku, alat tulis hingga jemputan bus sekolah yang semuanya gratis. Selain itu siswa juga memperoleh tas, tablet, pembebasan SPP hingga uang gedung dan kedepan, setiap siswa akan menerima uang saku gratis dan sepeda gratis.

\section{HAMBATAN DAN SOLUSI PEMERINTAH KOTA BLITAR DALAM MENJALANKAN PROGRAM APBD PRO RAKYAT DI BIDANG PENDIDIKAN KOTA BLITAR}

Ketentuan dalam Undang-Undang Nomor 23 Tahun 2014 tentang Pemerintah Daerah yang mengalihkan wewenang untuk menyelenggarakan pendidikan menengah yang berlaku pada pemerintah kabupaten/kota saat ini beralih kepada pemerintah provinsi. Dengan demikian, kerugian yang diderita oleh Pemohon adalah, pertama tidak dapat menetapkan kebijakan pendidikan menengah sebagai salah satu kebijakan pendidikan menengah gratis kepada masyarakat Kota Blitar. Seperti yang dilakukan oleh pemerintah kota Blitar dengan upaya pemerataan pendidikan gratis yang diberikan untuk semua jenjang pendidikan. Hambatan tersebutlah yang membuat Pemerintah Kota Blitar lebih berhati - hati dalam mengambil keputusan untuk lebih menjalankan program APBD Pro Rakyat khususnya terhadap pendidikan agar tidak terjadi kesenjangan antara Pemerintah Provinsi.

Beberapa permasalahan yang menjadi kendala atau hambatan Program APBD Pro Rakyat terhadap pendidikan adalah:

1. Kondisi ekonomi masyarakat yang menuntut anak untuk bekerja membantu ekonomi dari pada harus bersekolah.

2. Ada anggapan awal bahwa orang tua secara ekonomi tidak akan mampu menyekolahkan anaknya.

3. Kemampuan Pemerintah dalam mengalokasikan anggaran Program Pendidikan Gratis masih kurang memadai walaupun terus ditingkatkan.

4. Jumlah lembaga sekolah dasar masih kurang dan penyebarannya tidak merata.

5. Masih adanya perusahaaan yang mempekerjaan anak cukup lulusan SMP atau sederajat. Faktor Penghambat :

a. Belum memadainya jumlah tenaga yang menguasai perencanaan dan penelitian serta pengkajian pendidikan.

b. Belum tersedianya data - data pendidikan yang tersusun secara sistematis dan akurat sehingga menimbulkan kendala dalam proses perencanaan pembangunan pendidikan yang komprehensif dan berkelanjutan.

c. Belum memadainya kemampuan untuk menyusun suatu kerangka pembangunan pendidikan strategis yang benar - benar mencerminkan kondisi, potensi dan kebutuhan masyarakat. 
d. Belum optimalnya kegiatan penelitian dan pengkajian sebagai dasar pengambilan keputusan dalam proses perencanaan pembangunan pendidikan.

Masih terdapatnya kebijakan pembangunan daerah yang seringkali tidak berpihak pada kepentingan masyarakat.

Isu-Isu Penting Penyelenggaraan Tugas dan Fungsi Dinas Pendidikan Kota Blitar. Dalam pelaksanaan tugas dan fungsinya, Dinas Pendidikan Kota Blitar tidak dapat terlepas dari isu - isu strategis yang melingkupinya. Isu - isu strategis dimaksud antara lain :

1. Sumber daya manusia yang terbatas, yang belum sepenuhnya diarahkan pada pencapaian tujuan dan sasaran organisasi sehingga belum optimal;

2. Pengelolaan anggaran yang belum sepenuhnya mengarah kepada peningkatan kinerja;

3. Belum tersedianya data - data pembangunan pendidikan yang tersusun secara sistematis dan akurat sehingga menimbulkan kendala dalam perencanaan pembangunan yang komprehensif dan berkelanjutan;

4. Belum optimalnya pelaksanaan monitoring dan evaluasi program - program pendidikan yang dikaitkan dengan dokumen - dokumen perencanaan;

5. Pengaruh Globalisasi yang membuat semakin pesatnya perkembangan teknologi dan diberlakukannya perdagangan bebas;

6. Perubahan peraturan perundang - undangan sehingga belum sepenuhnya dapat terintegrasi secara baik sehingga dapat menghambat pencapaian tujuan pembangunan nasional dan daerah;

7. Belum meratanya kualitas SDM Perencana;

8. Masih belum optimalnya kapasitas kelembagaan untuk mendukung peningkatan kinerja Dinas Pendidikan Kota Blitar.

Berjalannya program APBD Pro Rakyat diharapkan konsep tersebut akan semakin banyak dipahami oleh masyarakat. Konsep ini bertujuan untuk meningkatkan kesejahteraan dan memberdayakan masyarakat. Pemerintah wajib mengusahakan pendidikan pada warga negaranya. APBD Pro Rakyat harus ditujukan sebesar-besarnya untuk belanja pelayanan dasar, khususnya pelayanan pendidikan.

Kesimpulan penjelasan diatas bahwa Pemerintah Kota dalam menjalankan APBD Pro Rakyat khususnya terhadap pendidikan memang terdapat hambatan yaitu apabila adanya kesenjangan dari beberapa Kota/Kabupaten lainnya yang mengakibatkan Pemerintah Pusat harus ikut serta untuk menyelesaikan kesenjangan ini. Dan seperti hal yang diketahui bahwa saat ini untuk Pendidikan Menengah sudah diambil alih oleh Pemerintah Provinsi. Adanya pola piker yang buruk dari lingkungan dan masih kurangnya anggaran dalam mewujudkan semua visi misi dari APBD Pro Rakyat itu sendiri.

Adapun solusi dari hambatan menjalankan program APBD Pro Rakyat di bidang pendidikan kota Blitar adalah :

1. Mengoptimalkan Sumber Daya Manusia ;

2. Pengelolaan anggaran harus terolah dengan baik;

3. Harus tersedianya data - data pembangunan pendidikan yang tersusun secara sistematis dan akurat ;

4. Evaluasi program - program pendidikan yang dikaitkan dengan dokumen - dokumen perencanaan harus optimal; 
5. Mengoptimalkan kapasitas kelembagaan untuk mendukung peningkatan kinerja Dinas Pendidikan Kota Blitar.

Secara khusus solusi program pendidikan gratis di Kota Blitar sebagai berikut:

a. Menggratiskan biaya operasi non personalia sekolah, dan sebagian biaya peserta didik bagi siswa SD/MI, SDLB, SMP/MTs, SMPBL, SMA/MA, SMALB, dan SMK yang diselenggarakan oleh Pemerintah Kota Blitar.

b. Meningkatkan beban biaya operasional sekolah dan sebagian biaya pribadi peserta didik bagi siswa yang menuntut ilmu di satuan pendidikan di wilayah Kota Blitar yang bukan diselenggarakan oleh Pemerintah Kota Blitar.

Dinamika Faktor Pendukung yang terjadi selama proses pelaksanaan program pendidikan gratis di Kota Blitar, diantaranya :

a. Adanya komitmen pejabat pelaksana yang lebih memprioritaskan pendidikan di atas sektor yang lain. Hal tersebut nampak pada anggaran APBD Kota lebih diutamakan untuk sektor pendidikan.

b. Mengurangi regulasi pengelolaan pendidikan bahkan sekarang terjadi tarik ulur pengalihan kewenangan pengelolaan pendidikan menengah/kejuruan.

c. Perlunya peran serta masyarakat yakni wali murid untuk menunjang keberhasilan program tersebut.

d. Pihak sekolah diharapkan lebih jelas lagi dalam hal memberikan informasi kepada siswa dan wali murid agar tidak terjadi salah penafsiran terhadap program pendidikan gratis.

\section{KESIMPULAN}

Pelaksanaan APBD Pro Rakyat pada bidang pendidikan di Kota Blitar tahun 2016 sudah mampu berjalan dengan baik mencapai 50,59\% seperti yang tertuang dalam pasal 49 Undang-Undang Nomor 20 Tahun 2003 tentang Sistem Pendidikan Nasional ayat (1) yang berbunyi : "Dana pendidikan selain gaji pendidik dan biaya pendidikan kedinasan dialokasikan minimal 20\% dari Anggaran Pendapatan dan Belanja Negara (APBN) pada sektor pendidikan dan minimal 20\% dari Anggaran Pendapatan dan Belanja Daerah (APBD)."

1. Adapun hambatan Program APBD Pro Rakyat terhadap pendidikan adalah:

1. Kondisi ekonomi masyarakat yang menuntut anak untuk bekerja membantu ekonomi dari pada harus bersekolah.

2. Ada anggapan awal bahwa orang tua secara ekonomi tidak akan mampu menyekolahkan anaknya.

3. Kemampuan Pemerintah dalam mengalokasikan anggaran Program Pendidikan Gratis masih kurang memadai walaupun terus ditingkatkan.

4. Jumlah lembaga sekolah dasar masih kurang dan penyebarannya tidak merata.

5. Masih adanya perusahaaan yang mempekerjaan anak cukup lulusan SMP atau sederajat.

Sedangkan solusi dari hambatan menjalankan program APBD Pro Rakyat di bidang pendidikan kota Blitar adalah :

1. Mengoptimalkan Sumber Daya Manusia ;

2. Pengelolaan anggaran harus terolah dengan baik ; 
3. Harus tersedianya data - data pembangunan pendidikan yang tersusun secara sistematis dan akurat;

4. Evaluasi program - program pendidikan yang dikaitkan dengan dokumen - dokumen perencanaan harus optimal;

5. Mengoptimalkan kapasitas kelembagaan untuk mendukung peningkatan kinerja Dinas Pendidikan Kota Blitar;

Secara khusus solusi program pendidikan gratis di Kota Blitar sebagai berikut:

a. Menggratiskan biaya operasi non personalia sekolah, dan sebagian biaya peserta didik bagi siswa SD/MI, SDLB, SMP/MTs, SMPBL, SMA/MA, SMALB, dan SMK yang diselenggarakan oleh Pemerintah Kota Blitar.

b. Meningkatkan beban biaya operasional sekolah dan sebagian biaya pribadi peserta didik bagi siswa yang menuntut ilmu di satuan pendidikan di wilayah Kota Blitar yang bukan diselenggarakan oleh Pemerintah Kota Blitar.

Melihat pada hasil penulisan dan analisa serta simpulan seperti dijelaskan di atas, maka dalam penulisan ini disarankan, sebagai berikut :

1. Dengan digratiskannya semua biaya sekolah, pelajar semakin fokus belajar. Program tersebut membuat sekolah lebih fokus memacu prestasi. Siswa juga menjadi lebih disiplin dan tidak ada alasan absen karena menunggak biaya sekolah. Agar warga Blitar lebih semangat untuk melanjutkan pendidikan setinggi-tingginya. Sekolah gratis dan angkutan gratis juga diharapkan meningkatkan kesejahteraan warga.

2. Diharapkan agar kesenjangan antara Pemerintah Provinsi dengan Pemerintah Kota Blitar tidak terjadi lagi, dikarenakan seperti halnya pelajar yang telah merasakan Pendidikan gratis dengan antusiasnya mereka dapat menempuh ilmu tanpa harus membebani orang tua mereka. Adapun solusi dari hambatan menjalankan pendidikan gratis di Kota Blitar dapat berjalan dengan baik. 


\section{DAFTAR PUSTAKA}

Buku:

Amiruddin, Asikin Zainal H. Pengantar Metode Penelitian Hukum, Jakarta: PT Raja Grafindo, 2004.

Bagian Hukum SETDA Kota Blitar, Peraturan Menteri Dalam Negeri, 2014.

Majalah Dinamika Kota Blitar, "Mengawal APBD Pro Rakyat", Edisi 2015.

Pemkot Blitar, Metafora APBD Pro Rakyat. Kota Blitar, 2012.

Soejito Irawan, Hubungan Pemerintah Pusat dan Pemerintah Daerah, Jakarta: Rineka Cipta, 1990.

Suhadak, Trilaksono Nugroho, Paradigma Baru "Pengelolaan Keuangan Daerah Dalam Penyusunan APBD di Era Otonomi.". CV. Bayumedia Publishing, 2007.

Sunggono, Bambang, S.H.,M.S., Metodologi Penelitian Hukum, Jakarta: PT Raja Grafindo Persada, 2005.

Tilaar, H.A.R., 50 Tahun Pembangunan Pendidikan Nasional 1945-1995,Jakarta: Grasindo, 1995.

\section{Perundang-Undangan :}

Undang-Undang Dasar Negara Republik Indonesia Tahun 1945

Undang-Undang Nomor 23 tahun 2014 tentang Pemerintahan Daerah

Undang-Undang Nomor 20 tahun 2003 tentang Sistem Pendidikan Nasional

\section{Internet:}

http://www.beritaekspres.com/2016/02/25/walikota-blitarbedah-apbd-pro-rakyat-didepan-insan-media/

http://www.blitarkota.go.id

http://www.budidarma.com/2011/11/anggaran-pendapatan-dan belanjadaerah.html

http://id.wikipedia.org/wiki/Sekretariat_daerah

http:// kotablitar.jdih.jatimprov.go.id

http://lauepu.blogspot.com/ 2015/ 02/ apbd-pro-rakyat.html 